\title{
Correction to: Religious change in Orthodox-majority Eastern Europe: from Nation-State to Global-Market
}

\section{François Gauthier ${ }^{1}$}

Published online: 15 October 2021

(c) Springer Nature B.V. 2021

\section{Correction to: Theory and Society https://doi.org/10.1007/s11186-021-09451-3}

The original article has been updated. The duplicate Acknowledgements were removed and updated. In the following sentence several words were omitted; these have now been added:

Politically, the consequences were the fragmentation of the three multi-ethnic or multi-national states into a myriad of independent states, either violently (Yugoslavia especially but also in many places within the ex-Soviet Union) or peacefully (Czechoslovakia or the Baltic states, cf. Rimestad, 2012, for the latter).

Publisher's Note Springer Nature remains neutral with regard to jurisdictional claims in published maps and institutional affiliations.

The original article can be found online at https://doi.org/10.1007/s11186-021-09451-3.

François Gauthier

francois.gauthier@unifr.ch

1 Science des religions, Social Sciences Department, Université de Fribourg, Fribourg, Switzerland 